
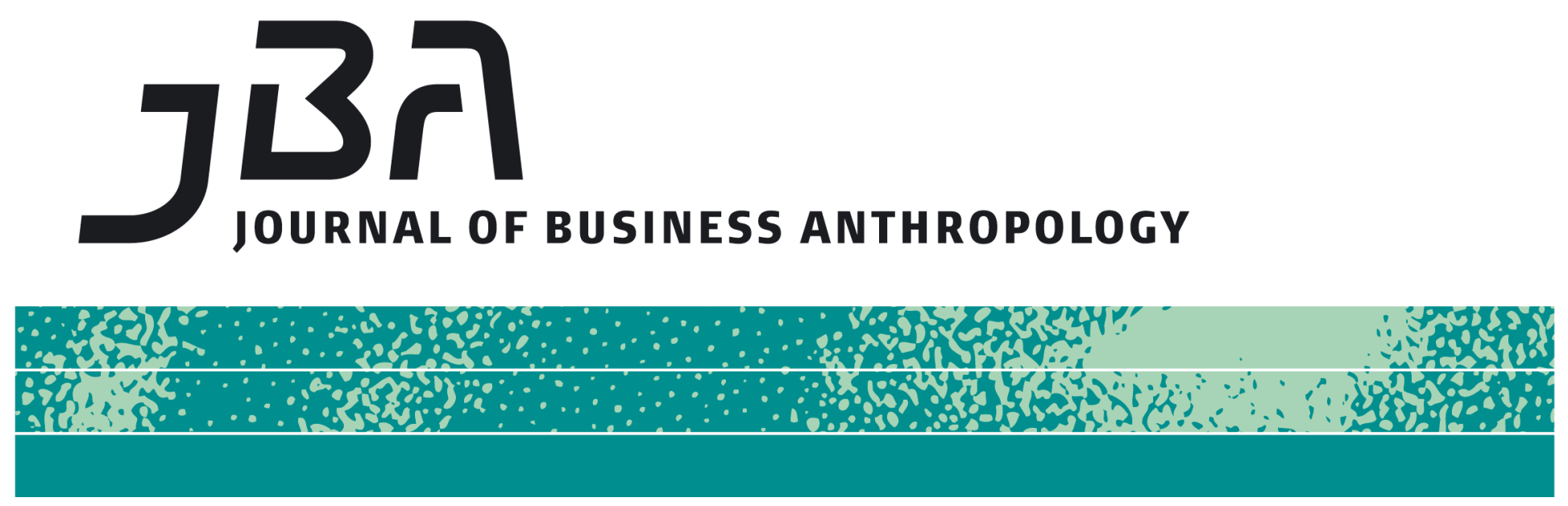

\title{
Cows, Pigs, Corporations, and Anthropologists
}

\author{
Donald D. Stull
}

\begin{abstract}
"Industrial meat" is produced by many actors-from growers to eaters, from processors to retailers, from multinational corporations to unauthorized immigrant workers. It epitomizes what Joseph Schumpeter called capitalism's "creative destruction," as companies rise and fall, all the while providing meat to an ever expanding population. For three decades, the author has critically examined the social, economic, and environmental consequences of the meat and poultry industry for livestock producers, processing workers, and host communities in Kansas, Nebraska, Oklahoma, and Kentucky. His research has taken him not only to farms and ranches, but also to the killfloors of massive meatpacking plants. He has worked with local governments and community groups as well as union and industry representatives to apply knowledge gained from his research, and he is actively involved with advocacy groups to resist and reverse the negative consequences of the corporate concentration and vertical integration that define industrial meat and poultry production. From experience-distant research on the industry to experience-near fieldwork for the industry, the author has employed long-term, multisited ethnography to build an ethnology of the modern meat and poultry industry, and the food factories that produce and process its products.
\end{abstract}

JBA 6(1): 24-40

Spring 2017

(C) The Author(s) 2017

ISSN 2245-4217

www.cbs.dk/jba 


\section{Keywords}

meat and poultry industry; applied anthropology; ethnography; United States

Over the course of the $20^{\text {th }}$ century, American agriculture relentlessly industrialized. Small, largely self-sufficient farms, relying on a mixture of crops, livestock, and wild foods gave way to highly mechanized and highly capitalized large ones, producing a limited range of crops for commodity markets. As control of our food system shifted from independent farms to highly concentrated and vertically integrated corporations, agriculture became an industry, manufacturing food, fiber, and fuel.

Meat is what Mary Douglas (1970) called a natural symbol, the "the food most directly associated with the idea of both symbolic and functional power" (Montanari 2006:123). It has also become "the symbol of a balance needing to be restored" (ibid.:122). "Industrial" meat is the product of many actors - from growers to eaters, from processors to retailers, from multinational corporations to unauthorized immigrant workers (Phillips 2006:41). It epitomizes what Joseph Schumpeter (1947) called capitalism's "creative destruction," as companies rise and fall, all the while providing meat to an ever expanding population. The Beef Trust that dominated North America early in the 20th centurySwift, Cudahy, Morrill, Armour, and Morris-survives only in a few brand names. Ironically, the very firms that supplanted those earlier giants by revolutionizing the industry in the 1960s and 1970s-IBP and ConAgra Red Meats-have disappeared as well, absorbed by a new generation of companies, most notably Tyson and Brazilian-owned JBS.

What follows is a brief "confessional tale" (Van Maanen 2011) about my ethnographic research on the North American meat and poultry industry over the past three decades, and my efforts to apply what I have learned to the mitigation of its negative consequences for host communities, processing workers, and livestock and poultry producers. It is also a "critical tale" of the challenges anthropological advocates and, for that matter, activists of any kind face in bringing reforms to an industry entrenched in a multinational oligopoly.

\section{Garden City, Kansas, where it all began}

I came to the study of the meat and poultry industry in a roundabout way. After the opening of IBP and Val-Agri (later ConAgra) beef plants in the early 1980s, the population of Garden City, Kansas, jumped by one-third to become the state's fastest growing community. Most of the newcomers who flocked to jobs in these plants were refugees from Southeast Asia and immigrants from Mexico and Central America. Beginning in the summer of 1987, I led a team that investigated changing ethnic relations in Garden 
City, as part of the Ford Foundation's national study of what was then called the new immigration (see Lamphere 1992). Overwhelmingly Anglo and agrarian at the beginning of the 1980s, by the time we arrived, Garden City was in the midst of dramatic social and cultural transformations that presaged a tide of economic and demographic change that was to sweep across rural North America in the years ahead (see, for example, Gozdziak and Martin 2005).

We submitted our final report to the Ford Foundation in February 1990 (Stull et al. 1990). It concluded with a series of recommendations to the people of Garden City on education, housing, health care, day care, and social services. In collaboration with the school district, we organized an advisory board representing public school teachers, city government, Garden City's three main ethnic groups, and service organizations. We worked with this committee to fine tune our recommendations and present them to appropriate institutions and agencies.

Social service agencies used our findings to obtain external funds. The school district revised policies and procedures on curriculum, bilingual and English as a second language (ESL) instruction, extracurricular activities, community outreach, personnel training, evaluation, and retention with our recommendations in hand. The city commission established a cultural relations board with wide community and ethnic representation, and local law enforcement sought to increase its minority personnel.

\section{From community ethnography to industry ethnology}

What we did not know as we concluded more than two years of fieldwork was whether the changes we witnessed in Garden City also confronted other packinghouse towns. Over the next decade, social geographer Michael Broadway and I studied Lexington, Nebraska, where IBP opened another beef plant in 1990, and Guymon, Oklahoma, which attracted a Seaboard pork plant. Broadway launched a study of Brooks, Alberta, Canada, which became home to an IBP beef plant. I turned my attention to my birth community in western Kentucky, which in the mid-1990s began sprouting the commonwealth's newest cash crop-chickens-and the plants to process them. 


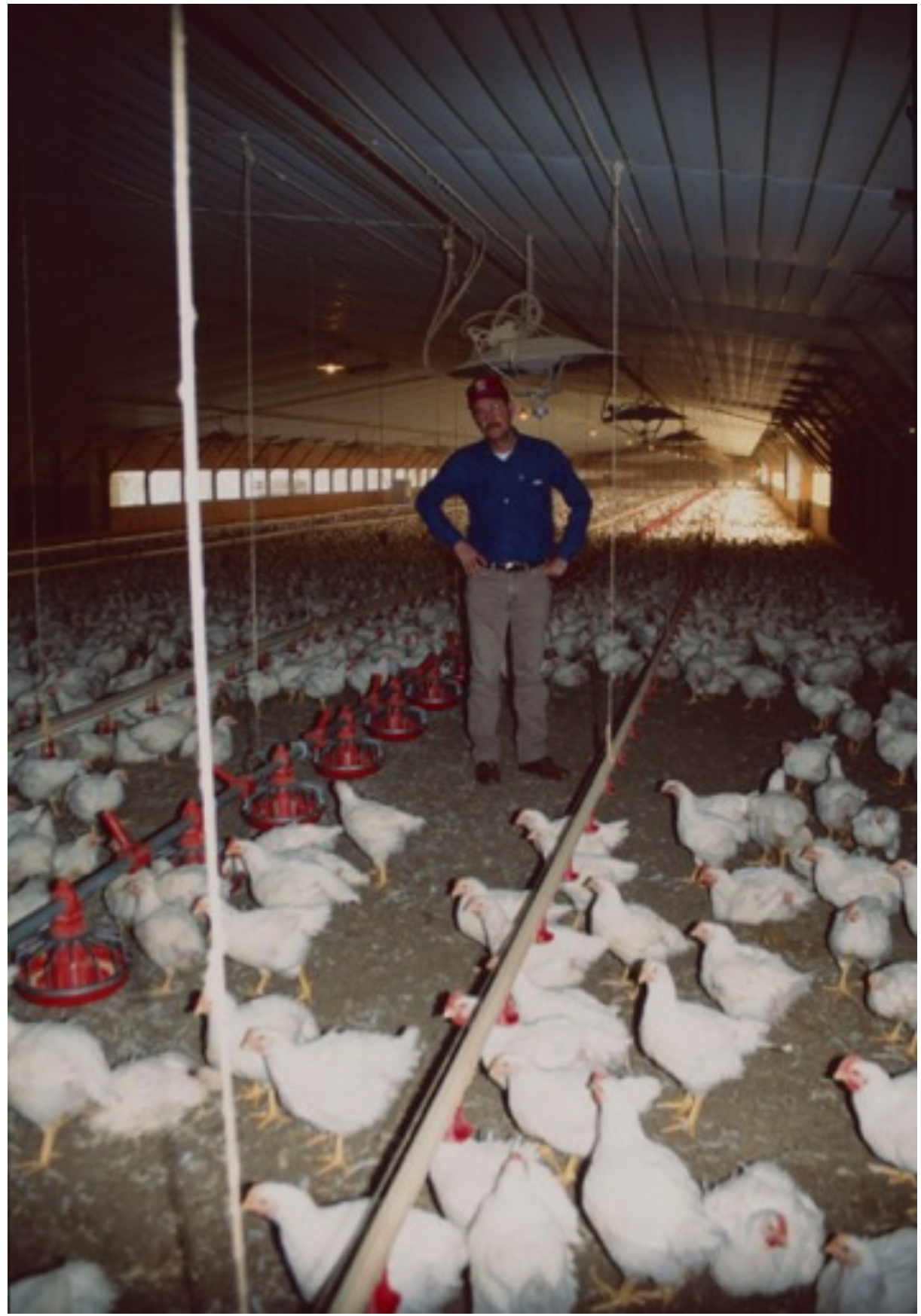

Figure 1: Don Stull stands between feeding trays and a water line inside a western Kentucky broiler house in 1998. Each house holds some 25,000 broilers (eating chickens), which are grown to maturity in about seven weeks.

Like Garden City, each of these places faced rural industrialization and rapid growth, creating an array of problems common to so-called boomtowns: population mobility, severe housing shortages, soaring school enrollments, rising rates of crime and social ills, inadequate medical services, strains on infrastructure and social services, dramatic increases in cultural and linguistic diversity, and environmental concerns. 
Our ethnography of Garden City, intended to explore ethnic relations between native-born Kansans and new-immigrant Mexicans and Vietnamese, became an extended natural experiment, evolving into an ethnology of the meat and poultry industry and its impact on host communities, processing workers, producers, and the environment. While our work has made significant scholarly contributions, its greatest value, we believe, has been to inform communities of the consequences of the meat and poultry industry and help them prepare for and mitigate its impact. To that end we have consulted with and provided technical assistance to a number of communities in the United States and Canada. Our research combines the methods and insights of cultural anthropology and social geography. We favor longitudinal analysis of selected sites using long-term participant observation, in-depth interviews, and extensive review of pertinent documents. We have returned to Garden City periodically to update our research, especially following significant events, such as the fire on Christmas night 2000 that closed the ConAgra plant, putting 2,300 out of work (Broadway and Stull 2006). ${ }^{1}$

The first of what Crowley and Lichter (2009) call Latino boomtowns, which spread from the Midwest in the 1980s to the Southeast in the 1990s, Garden City is a prime example of what the U.S. Census Bureau now defines as micropolitans: "mini-metros with rural sensibilities" or "rurbans" (Francis 2005) that blend agricultural economies commonly associated with rural areas and immigration patterns typically associated with urban areas (Brown, Colmartie and Kulcsar 2004; Zehr 2005).

In addition to Garden City, we have carried out long-term research in two other places: Broadway in Brooks, Alberta, and me in western Kentucky. Our research has expanded beyond industry impact on communities to include its consequences for plant workers, growers, and the environment. Slaughterhouse Blues: The Meat and Poultry Industry in North America (Stull and Broadway 2004, 2013) provides an overview of our research and presents in depth the methods and findings from several of our studies.

Anthropologists (and some honorary anthropologists like Broadway) have led the way in documenting the environmental consequences of concentrated animal feeding operations (CAFOs) (Thu and Durrenberger 1998); the impact of the meat industry's restructuring and relocation on rural communities (Stull, Broadway, and Griffith 1995); the poor working conditions inside meatpacking plants (Grey 1999; Stull

\footnotetext{
1 Jennifer $\mathrm{Ng}$, associate professor of educational leadership and policy studies, University of Kansas, and I conducted ethnographic research for several months in 2013 on how Garden City's schools and educators have dealt with four decades of increasing and constantly changing ethnic, cultural, linguistic, and religious diversity (Stull and Ng 2016) Thus, in some sense, I have come full circle to the issues that brought me to Garden City in the first place.
} 
1994; Stull and Broadway 1995; Broadway and Stull 2008); and how essential immigrants are to meat processing (Horowitz and Miller 1999; Fink 2003).

Mark Grey, a member of the Garden City research team, founded and directs the Iowa Center for Immigrant Leadership and Integration. Located at the University of Northern Iowa, the Center's technical assistance and publications are valuable resources for communities and agencies facing the challenges of ethnic and linguistic diversity that accompany the meat and poultry industry (see, for example, Yehieli and Grey 2005).

Anthropological research has informed prize-winning exposés (Horwitz 1994), best-selling books (Schlosser 2001), and gripping documentaries (Food Inc.), which, in turn, have brought many of these issues to ever wider audiences. As a result, a growing number of Americans are now aware of how, where, and by whom their food is produced and processed. And they are increasingly concerned.

By the late 1990s, a loose, but growing coalition of secular and religious organizations was condemning the environmental, animal welfare, and social consequences of so-called factory farming. The research of Kendall Thu and his associates (Thu and Durrenberger 1998) fueled opposition to air and water pollution associated with industrial pork production. Our work drew attention from those concerned about industry impacts on workers, communities, environments, and animals. I was often asked to speak at public forums in towns where new packing plants were being proposed or were soon to be built. I became a regular source for news stories on meat-related issues, from the strike by Tyson workers in Jefferson, Wisconsin (Bill Moyers' NOW) to the first case of mad cow disease in the United States (New York Times) to President George W. Bush's proposed guest worker program and amnesty for unauthorized immigrants (Western Livestock Journal) to demonstrations across the nation for immigrant rights (New York Times) and concomitant fears of a reconquista (The Hutchinson [Kansas] News) to the recall of 500 million eggs after salmonella sickened 1,500 in the summer of 2010 (Dan Rather Reports). I have been featured on public radio talk shows and invited to write on industry concentration and working conditions for Corporate Social Responsibility Newswire's series Talkback.

But producing useful information, even if it reaches broad audiences, is not enough. Anthropologists and other social scientists must find better ways to influence users of that information. One such opportunity seemed to come my way from a most unexpected directionthe corporate office of a major meatpacking firm. 


\section{On the packinghouse floor}

Late in the summer of 1992, the "Running Iron" beef plant in the midwestern town of "Valley View" abruptly announced it would change second-shift fabrication hours from 1:15-9:45 p.m. to 3:15 p.m.-1:45 a.m. The next day 38 workers called in sick-22 of them were fired. Their termination triggered a wildcat strike by some 200 workers who walked off the job, citing unfair treatment, racism, poor working conditions, an unsafe workplace, and low morale. Running Iron was an industry leader in wages and benefits, and the work stoppage caught management and union officials alike by surprise.

In the settlement it reached with striking workers a week later, Running Iron agreed to change operations of second-shift fabrication lines, adequately staff crews, improve communication between workers and management, and rehire strikers. As part of the settlement, Running Iron and its union formed a joint cultural diversity committee to address issues raised by the striking workers, most of whom were Mexican immigrants. Corporate executives were concerned with their "inability to recognize cultural differences and then manage them." They wanted outside researchers to identify concerns of management and labor, recommend changes, and work with them to implement improvements. A year after the strike, the company's labor relations officer invited me to propose such a study. [I later learned the invitation came in part because of a paper I had written: "Dances with Cows." The industry executives who awarded me the research contract liked the title, and the fact that it criticized their primary competitor. An expanded version of the paper later appeared as Gouveia and Stull (1995).]

I asked Ken Erickson, a practicing anthropologist and a former member of the Garden City research team who speaks Spanish and Vietnamese, and the late Miguel Giner, an industrial psychologist and Mexican immigrant, to join me on the project. We studied Running Iron's Valley View beef plant for eight months in 1994.

The executives who chose our proposal over several others expected us to survey a random sample using a standardized questionnaire, what they viewed as "proper scientific research." We convinced them that participant observation was more appropriate as a primary method. It began with a tour of the plant one Saturday in February. By August, we could give tours ourselves-and I did on one occasion. Our work days began at 7:00 a.m. with the "morning management meeting," and often did not end until the second shift shut down well after midnight.

We examined company and union policies and documents. We went through new-hire training. We talked with and interviewed managers, union officials and stewards, line supervisors and line workers, men and women, English and non-English speakers, Anglos, Hispanics, 
and Asians. Interviews were problem-focused and questions open-ended. Respondents were chosen for their knowledge or position (union business representative, plant manager, trainer, line worker) and to replicate workplace diversity (gender, ethnicity, department, job, shift). Our report addressed relations between Anglo plant managers and their multicultural workforce, recurrent complaints by hourly workers, and training for supervisors and new hires.

In February 1995, a year after we began our study, we presented our findings to company executives at corporate headquarters. Briefly, we found that the company had not one workforce, but two: one consisted of old-time packers who had been with the company for many years; the other was made up of newcomers, mostly Mexican immigrants. Company ideals of safety, quality, productivity, and loyalty were widely shared by both groups, but their interpretations of these ideals and how to achieve them often differed. Breakdowns and contradictions between company ideals and managerial behaviors often led to resentment and conflict between workers and managers. Especially problematic was the tension between the stated ideal of "safety first" and managers' constant efforts to reduce costs and increase product output. Invariably, safety (and product quality) took a backseat to "getting it out the door."

Corporate officials asked us to propose solutions to problems identified in our report. Three months later we submitted a proposal for a pilot training program for Running Iron supervisors. We never heard from the company again.

We were, however, invited to present our findings at a major industry convention and publish our findings in Meat\&Poultry magazine, the industry's leading trade journal (Stull, Erickson, and Giner 1996). I have maintained good relations with the union and have been invited to speak at their conventions. But I have never again been asked to work with any meat or poultry company.

The working conditions that spawned the walkout are endemic in the meat and poultry industry. Managers will tell you they care about their workers and they spend huge sums on training, but they will also tell you employee turnover and elevated rates of occupational injury and illness are the price of doing business. Despite what managers say, solutions to the problems that continue to plague Running Iron-and the rest of the industry-are no mystery. Pay a fair wage. Provide better and longer periods of training for supervisors and line workers. Adequately staff work crews. Vary job tasks to relieve muscle strain. Provide longer recovery periods for injured workers. Most of all, slow down the chain.

Fifty years ago, Tom Lupton (1963:201) concluded his shop-floor ethnography in a similar vein: "management would be better employed in putting its technical house in order than [in] complaining about ... the workers." 
But, as the late Del Jones (1976:222-223) said in "Applied Anthropology and the Application of Anthropological Knowledge":

[0]ne does not influence policy through the collection of accurate information but through pressure politics. It is also true that policymakers could do a better job if they utilized accurate and complete information. But this will not come about until the producers of information organize as a pressure group, or work through pressure groups, to influence the users of information. At the least it should be the responsibility of the producers of information to make sure that relevant facts are made available to appropriate parties.

I have studied the meat and poultry industry for 30 years, making "sure that relevant facts are made available to appropriate parties" and doing my best to influence policy makers. But as Jones (ibid: 222) also observed:

[I]t is almost a perverse arrogance to even assume that information collected will automatically be used by policymakers. That "useful" information may be known and not utilized by policymakers is itself a policy decision. Political processes are not guided so much by truth as by political ideology, group interest, pressure politics.

The executives who hired us to help them "recognize cultural differences and then manage them" knew what we would find. They commissioned our study to mollify disaffected workers and the union in the wake of a strike, not to be a catalyst for improved working conditions.

To $19^{\text {th }}$ century cattle barons, who worked their cowboys long hours at dangerous jobs for short pay: "Men were cheap, cattle cost money" (Adams 1903:52). To the men who sit in the boardrooms of the $21^{\text {st }}$ century corporations that control the meat and poultry industry, and those who do their bidding in its massive factories, workers are still cheap. And cattle, hogs, and chickens still cost money.

\section{Corporate control of America's food system}

American agriculture is controlled by large corporations like Running Iron. Virtually all chickens sold in the United States are grown under production contracts to a handful of companies, who own the birds from egg to supermarket. Tyson Foods, the largest U.S. poultry company, contracts with about 6,000 of what it calls family farmers to raise its chickens. They are expected to grow birds to slaughter weight under strict company guidelines as quickly and as cheaply as possible. If Tyson is not satisfied, it may cancel growers' contracts with little notice and even less recourse, leaving them under a mountain of debt for their otherwise useless chicken houses. 
Nine out of 10 hogs are owned directly by or raised under contract to companies like Smithfield or Tyson. More than half of the cattle now slaughtered in the United States are secured through what is known as captive supply: they are owned directly by corporations, raised under contract or according to company specifications, or sold by feeders that have only one viable buyer. And the companies that bring us our burgers, bacon, and wings are very often one and the same.

The Packers and Stockyards Act of 1921 makes it unlawful for meat and poultry companies to engage in "unfair, unjustly discriminatory, or deceptive practice" [or to] "give any undue advantage to any particular person ... or subject any particular person to undue disadvantage." Congress and the U.S. Department of Agriculture (USDA) have done little to enforce this law. Meanwhile, concentration and vertical integration have destroyed meaningful competition in livestock and poultry markets to the detriment of both farmers and eaters.

In his first term, President Obama promised to reform American agriculture through vigorous antitrust enforcement. And Congress included language in the 2008 farm bill to require the Department of Agriculture to write regulations, using the Packers and Stockyards Act, to restore fairness and competition in livestock and poultry production. In 2010, the USDA and the Department of Justice held joint workshops across farm country to hear from producers-60,000 comments were received. But some voices are louder than others. Under pressure from the interests that dominate industrial agriculture, Congress refused to either approve or fund enforcement of almost all of the proposed reforms.

\section{Organization for competitive markets}

In 1998, I joined with a group of concerned farmers, ranchers, economists, and social scientists in Kansas City to found the Organization for Competitive Markets. OCM is a nonprofit research and advocacy group dedicated to fighting concentration and vertical integration in agricultural markets. In 2011, I was elected to its board of directors and currently serve as its vice-president.

OCM was active in the successful campaign to require country of origin labeling (COOL) of meats and some other agricultural products. Labels were first required in 2002, but the meat industry vigorously opposed full implementation. In February 2015, the U.S. District Court for the District of Columbia dismissed a lawsuit brought by the American Meat Institute and the multinational meatpacking corporations it represents to stop the USDA from implementing this popular law. But later that year the World Trade Organization (WTO) upheld complaints by Canada and Mexico that COOL put their meat and livestock at competitive disadvantage in U.S. markets. WTO threatened to impose a $\$ 1$ billion in retaliatory import tariffs if COOL was not repealed. The repeal 
was included in an omnibus spending bill signed into law by President Obama in December 2016.

Efforts to stem corporate dismantling of livestock markets and egregious mistreatment of poultry and livestock producers have yet to succeed (see Stull and Broadway 2014:60 for one example of a failed attempt). One arena where OCM believes it may be able to weaken corporate control over livestock production is the "beef checkoff."

The Beef Promotion and Research Program, commonly called the beef checkoff, assesses cattle owners $\$ 1.00$ each time an animal is sold. The checkoff program was created to promote beef consumption through research and marketing. Remember "Beef, it's what's for dinner" - that was checkoff dollars at work. Similar checkoff programs exist for pork, milk, and other agricultural products. The beef checkoff is administered by the board of the National Cattlemen's Beef Association (NCBA). In 2010 a performance review of 1 percent of transactions over 29 months by an independent auditor found the NCBA had misappropriated $\$ 217,000$. No penalties were imposed. The NCBA continues to operate as the prime contractor for the beef checkoff, from which it derives over 70 percent of its operating expenses. This audit raised serious concerns about what the NCBA does with the $\$ 80$ million from cattle producers each year.

In August 2012, OCM joined with the Humane Society of the United States (HSUS) to mount a legal challenge to the beef checkoff program. The suit maintains that the NCBA misused checkoff dollars to lobby against country of origin labeling and to support meatpacking firms to the detriment of small farmers and ranchers, whose numbers have fallen sharply since the checkoff was implemented. OCM and HSUS continue to seek access to 40,000 pages of unreleased documents under the Freedom of Information Act (McGraw and Lowe 2015).

With 11 million members and assets in excess of $\$ 100$ million, HSUS is the most influential animal welfare organization. Many farmers and ranchers view HSUS as the enemy, and OCM was sharply criticized and lost members when we joined with HSUS. But OCM and HSUS agree that only by joining forces can farmers and eaters hope to bring about significant change in our food system.

The forces of creative destruction in the meat and poultry industry have affected plant locations and labor force composition, and they have stymied efforts by unions, farmers, politicians, scholars, journalists, and activists to reform it. It has been more than a century since the first, and still the best known, expose of the meatpacking industry-Upton Sinclair's The Jungle-appeared. Its publication in 1906 prompted the passage of the Meat Inspection Act and the Pure Food and Drug Act. In 1999, journalist Eric Schlossier reignited public concern over the meat industry with Fast Food Nation, which was made into a motion 
picture and inspired the popular documentary Food Inc. Industry exposés continue to pile one on top of another. Foodopoly: The Battle over the Future of Food and Farming in America (Hauter 2012); The Meat Racket: The Secret Takeover of America's Food Business (Leonard 2014); The Chain: Farm, Factory, and the Fate of our Food (Genoways 2014) are the best examples of recent investigative journalism on the meat industry.

The crescendo of scholarly and journalistic indictments of the industry has certainly raised public awareness. But Upton Sinclair's (1962:126) famous lament- "I aimed at the public's heart and by accident I hit it in the stomach" - is shared by today's would-be reformers. The American public is quick to react to reports of evils lurking in their meat and when abuses are heaped upon the animals from which it is made. The industry has reluctantly responded to mounting public pressure to reduce nontherapeutic use of antibiotics in animal production and to treat farmed animals more humanely. But repeated exposés of low wages and oppressive working conditions in meat and poultry plants, as well as corporate practices that have destroyed competitive and equitable livestock and poultry markets, raise scant concern with eaters or policy makers. If anything, things may be getting worse. As just one example, in October 2014, the USDA approved the New Poultry Inspection System (NPIS) that allows turkey and chicken processing plants to increase line speeds and replace most government inspectors with company employees (USDA 2014).

America's food system remains in the grasp of an oligopoly of multinational corporations, and the factory system it has created remains the dominant model of meat production and processing. Alternative production models in which animals are raised locally and sustainably on family farms under socially just conditions have reemerged, however. Whether they will effectively challenge the hegemony of industrial meat production for all but the wealthiest eaters in high-income nations remains to be seen.

In January 2015, OCM and HSUS convened a meeting of representatives of other organizations that also work to end the abuses of industrial agriculture and develop viable alternative food systems. Slow Food USA, Food for America, the New America Foundation, the Farmers Union, and the United Food and Commercial Workers were among those represented. These organizations and many others have pursued individual goals: animal welfare, competitive agricultural markets, sustainable agriculture, wholesome foods, environmental and social justice, better conditions for food processing workers. Even within these general movements, efforts have been fragmented and poorly coordinated. The goal of this meeting was to begin to build networks and develop collaborations. The long-range goal is to develop and implement effective challenges to the dominant food system and to nurture viable alternatives that are sustainable, fair, just, and affordable. Under OCM's 
leadership this collaboration has been formalized; it has established priorities and developed campaign strategies around each goal. Goals include passage of legislation ending marketplace abuses of commodity checkoff programs, promoting fair and just contracts for poultry growers, and pushing for adoption of the Good Food Purchasing Policy for public schools in several major U.S. cities.

The system that currently dominates production, processing, and distribution of our food is not likely to be replaced in the foreseeable future. But alternatives at each stage of the food chain have already emerged. The challenge is now to grow them, to make them more available and affordable. As one of the reviewers of this article reminded me, alternatives are much more viable today than when I began studying the industry 30 years ago. Farmers markets and expanding digital platforms bring food producers and eaters into direct contact. "Local," "sustainable," "organic," and "humanely produced" foods give progressive groceries and restaurants competitive advantage in more markets. As people become disenchanted with or afraid of "industrial" foods, they turn to alternative providers. If these new producers and processors resist the siren call to sell out to the companies that currently dominate the food system, we may yet see decentralized food systems as viable competitors to the concentrated and centralized system of today. But eaters must seek out these options, actively participate in them, and be willing to pay for their products. And emergent food providers must eschew the "cheap food" model of the dominant companies, the low wages and oppressive working conditions that have gone with it.

\section{"Shall we therefore mix science with politics?"}

Anthropologists have historically studied one people in one place for one year or so, then left, perhaps to return once in a while, but more often not. Increasingly ethnographers have "entered the corporation," to use Melissa Cefkin's (2009:1) apt phrase, "invited there to influence the organizations' understandings, and effectiveness and profits." By happenstance and by design, I have ended up studying one industry in scattered locations for three decades. I have examined each of its sectors-beef, pork, and poultry-on farms and ranches, in factories and towns, scattered across rural North America. I have looked at it from varied vantage points: the towns that host its massive plants; hourly line workers who make meat on its kill and fabrication floors; farmers and ranchers who grow its raw product.

This research has added to the social science of boomtowns. Rapid growth, high wages, and social disorders characterize energy boomtowns. Meatpacking has created a different kind of boomtown, with high turnover, minimal benefits, dangerous working conditions, low wages, and rising tides of impoverished residents (Broadway and Stull 2006). 
Some ethnographers have conducted clandestine research in meat and poultry plants (Fink 1998; Pachirat 2011; Strifler 2005). I have not. This has meant I have often been kept at a distance by industry gatekeepers, but clandestine researchers have uncovered no more than me. And as a Running Iron consultant, with my own company ID and parking place, I learned more than I could ever have dreamed possible. It was an opportunity that never would have come my way, had I masked my identity and intentions.

I have come to my research sites as a traditional outsider anthropologist and as a native ethnographer, living and working in my hometown among relatives and lifelong friends. I have been a basic researcher, an applied researcher, and an advocate. Had I not committed myself to the long haul, and had I not actively pursued broad exposure to the industry from diverse perspectives, I would never have seen what I have seen or learned what I have learned.

In an influential presidential address to the American Anthropological Association, which he called "The Anthropology of Trouble," Roy Rappaport (1993:295, 297) warned that to survive, let alone flourish, necessitates "the relocation of both engaged and domestic research from anthropology's periphery toward its center... To publish critiques of institutions or values in the society in which they prevail is, almost unavoidably, to support or subvert them... Increasing distance from value neutrality increases responsibility for precise, accurate, and well-grounded accounts. They need to stand up not only to critical reviewers but also to hostile lawyers."

My work, and that of other social scientists who have examined the meat and poultry industry, has stood up to critical reviewers and more importantly to a hostile industry, and its high-powered lawyers. But, in all honesty, they are more worried about disenchanted eaters who are voting with their forks and powerful interest groups that are influencing legislation and challenging industry practices in court.

American anthropology languishes at a crucial juncture, desirous of greater recognition and influence, but "branded" as peripheral to policy formation and the solution of contemporary social problems. It is imperative that we "direct the discipline toward the generation of knowledge that has some more useful purpose" (Blakey et al. 1994:297). None other than Malinowski himself declared that "research in order to be of use must be inspired by courage and purpose... Shall we therefore mix politics with science?... Decidedly 'yes.'” (quoted in Hackenberg and Hackenberg 1999:1). 


\section{References}

Adams, A. 1903 The log of a cowboy: a narrative of the old trail days. Boston: Houghton Mifflin.

Blakey, M. L., F. Dubinskas, S. Forman, C. MacLennan, K. S. Newman, J. L. Peacock, R. A. Rappaport, C. G. Velez-Ibanez, and A. W. Wolfe 1994 “A Statement to the profession: the American Anthropological Association Panel on Disorders of Industrial Societies." In S. Forman (ed.) Diagnosing America: anthropology and public engagement, pp. 295-311. Ann Arbor: University of Michigan Press.

Broadway, M.J. and D.D. Stull 2006 "Meat processing and Garden City, Kansas: boom and bust." Journal of Rural Studies 22: 55-66.

2008 "'I=ll do whatever you want, but it hurts': worker safety and community health in modern meatpacking." Labor 5(2):27-37.

Brown, D.L., J.B. Crowmartie, and L.J. Kulcsar 2004 "Micropolitan areas and the measurement of American urbanization." Population Research and Policy Review 23: 399-418.

Cefkin, M. 2009 "Business, anthropology, and the growth of corporate ethnography." In M. Cefkin (ed.) Ethnography and the corporate encounter: reflections on research in and of corporations, pp. 1-37. New York: Berghahn Books.

Crowley, M. and D.T. Lichter 2009 "Social disorganization in new Latino destinations." Rural Sociology 74: 573-604.

Douglas, M. 1970 Natural symbols. London: Barrie \& Rockliff.

Fink, D. 1998 Cutting into the meatpacking line: workers and change in the rural Midwest. Chapel Hill: University of North Carolina Press.

Fink, L. 2003 The Maya of Morgantown: work and community in the Nuevo New South. Chapel Hill: University of North Carolina Press.

Francis, L. 2005 "Micropolitan statistical areas redefine rural America." Http://www. unitedcountry.com/micropolitan.htm. Retrieved July 8, 2005.

Genoways, T. 2014 The Chain: farm, factory, and the fate of our food. New York: Harper-Collins.

Gouveia, L. and D.D. Stull 1995 "Dances with cows: beefpacking's impact on Garden City, Kansas, and Lexington, Nebraska.” In D. D. Stull, M. J. Broadway, and D. Griffith (eds.). Any way you cut it: meat processing and small-town America, pp. 85-107. Lawrence: University Press of Kansas. Gozdziak, E. and S. F. Martin 2005 Beyond the gateway: immigrants in a changing America. Lanham, Md.: Lexington Books.

Grey, M. 1999 "Immigrants, migration, and worker turnover at the Hog Pride Pork Packing Plant." Human Organization 58: 16-27. 
Hackenberg, R. A. and B. H. Hackenberg 1999 "You CAN do something! Forming policy for applied projects, then and now." Human Organization 58: $1-15$.

Hauter, W. 2012 Foodopoly: the battle over the future of food and farming in America. New York: New Press.

Horowitz, R., and M. J. Miller 1999 "Immigrants in the Delmarva poultry processing industry: the changing face of Georgetown, Delaware, and environs." JSRI Occasional Paper No. 37, The Julian Samora Research Institute. East Lansing: Michigan State University.

Horwitz, T. 1994 "Nine to nowhere: blues on the chicken line." Wall Street Journal, December 1: A1, A8-A9.

Jones, D. J. 1976 "Applied anthropology and the application of anthropological knowledge." Human Organization 221-230.

Lamphere, L. (ed.) 1992 Structuring diversity: ethnographic perspectives on the new immigration. Chicago: University of Chicago Press.

Leonard, C. 2014 The meat racket: the secret takeover of America's food business. New York: Simon \& Schuster.

Lupton, T. 1963 On the shop floor: two studies of workshop organization and output. Oxford: Pergamon.

McGraw, M. and P. Lowe 2015 "Ranchers take on the beef industry over mandatory checkoff payments.” Harvest Public Media, January 17.

Montanari, M. 2006 Food is culture. New York: Columbia University Press.

Pachirat, T. 2011 Every twelve seconds: industrialized slaughter and the politics of sight. New Haven: Yale University Press.

Phillips, L. 2006 "Food and globalization." Annual Review of Anthropology 35: 37-57.

Rappaport, R. A. 1993 “The anthropology of trouble." American Anthropologist 95: 295-303.

Scholsser, E. 2001 Fast food nation: the dark side of the all-American meal. New York: Houghton Mifflin.

Schumpeter, J. 1947 Capitalism, socialism and democracy. New York: Harper \& Brothers.

Sinclair, U. 1962 The autobiography of Upton Sinclair. New York: Harcourt, Brace, \& World.

Stull, D.D., ed. 1990 "When the packers came to town: changing ethnic relations in Garden City, Kansas." Urban Anthropology 19: 303-427.

1994 "Knock 'em dead: work on the killfloor of a modern beefpacking plant." In L. Lamphere, A. Stepick, and G. Grenier (eds.) Newcomers in the workplace: immigrants and the restructuring of the U.S. 
economy, pp. 44-77. Philadelphia: Temple University Press.

Stull, D.D., J.E. Benson, M.J. Broadway, A.L. Campa, K.C. Erickson, and M.A. Grey "Changing relations: newcomers and established residents in Garden City, Kansas." Final report to the Ford Foundation's Changing Relations Project Board, Binghamton, New York, February 5. Institute for Public Policy and Business Research Report No. 172.

Stull, D. D. and M. J. Broadway 1995 "Killing them softly: work in a modern beef plant and what it does to workers." In D. D. Stull, M. J. Broadway, and D. Griffith (eds.) Any way you cut it: meat processing and small-town America, pp. 61-83. Lawrence: University Press of Kansas.

2004 Slaughterhouse blues: The meat and poultry industry in North America. Belmont, Calif.: Wadsworth.

2013 Slaughterhouse blues: the meat and poultry industry in North America. Second edition. Belmont, Calif.: Wadsworth.

Stull, D. D., M. J. Broadway, and D. Griffith (eds.) 1995 Any way you cut it: meat processing and small-town America. Lawrence: University Press of Kansas.

Stull, D.D. and J. Ng 2016 "Majority educators in a U.S. minority/immigrant public school district: the case of Garden City, Kansas." Human Organization 75: 181-191.

Strifler, S. 2005 Chicken: the dangerous transformation of America's favorite food. New Haven: Yale University Press.

Thu, K. M. and E. P. Durrenberger (eds.) 1998 Pigs, profits, and rural communities. Albany: State University of New York Press.

USDA 2014 "Modernization of poultry slaughter inspection." Federal Register 79(162), August 21. 9 CFR Parts 381 and 500. Food Safety and Inspection Service, US Department of Agriculture.

Van Maanen, J. 2011 Tales of the field: on writing ethnography. Second edition. Chicago: University of Chicago Press.

Yehieli, M. and M.A. Grey 2005 Health matters: a pocket guide for working with diverse cultures and underserved populations. Yarmouth, ME: Intercultural Press.

Zehr, M.A. 2005. "Newcomers bring change, challenge to region: spike in English-learners strains resources, traditions." Education Week 24(34): 1, 18-19, 21.

Don Stull is professor emeritus of anthropology at the University of Kansas, where he taught from 1975 to 2015. He has been editor-in-chief of Human Organization, president of the Society for Applied Anthropology, and a recipient of the SfAA's Sol Tax Distinguished Service Award. In 2001 he was presented with the key to Garden City, Kansas, and made an honorary citizen in recognition of the value of his work to this community. 